\title{
建築材料としての無機高分子 ケイ酸カルシウム水和物の合成と応用
}

\section{高 橋 輝}

Akira Takahashi，大阪パッキング製造所

\section{1.はじめに}

1940 年代化無機化合物の分野で, シリコーンの出 現というすい゙らしい革新的発明があった。すなわち、 ケイ酸塩化合物の骨格となっているシロキサン結 合 ( $\mathrm{Si}-\mathrm{O}-\mathrm{Si}<)$ を主鎖とし，それにメチル基やフェ ニル基が側鎖となって枠づくりをして, シリコーンと 呼ばれる有機ヶイ素高分子が生み出された。 そして， シリコーンは第二次大戦中拉よび戦後に急速に発展 し，新材料として応用範囲は日を追って拡大してきて いる、シリコーンは明確にポリマーのイメージにつな がるものであるが，しかし，粘土鉱物や水ガラスなど のシロキサン結合の鎖からなるものや, あるいは，ポ リリン酸骨格の鎖の化合物などは一般に高分子とは呼 ばれていなかった。

C. W. Lentz $z^{1)}$ はポルトランドセメントの水和物で あるケイ酸カルシウム化合物をトリメチルシリル化す ることによって，炎の化合物がシロキサン鎖の骨格構 造を有する無機高分子で步ることを明らかにし，その 重合度が 15.8 で西ることを示した，その他，天然や 合成鉱物の無機化合物汇ついて子調べ，無機高分子の 存在を明らかにした。

無機高分子の定義としては次の三つの分類がなされ ている2).

（1）主鎖骨格と側鎖（枠らくり基）のすべてが無 機元素からなるもの

(2) 主鎖骨格のみが無機元素で構成し，側鎖には 有機基をるっているもの

(3) 主鎖骨格に部分的に無機元素が入り，かつ主 鎖側鎖ともに有機基をむっているもの

(2), (3) Кついては多くの研究がなされ, 中でるシ リコーンが代表的なるのである（1）の部類淿属する

Inorganic Polymer for Building Materials.
無機高分子は天然にも合成沉も存在する古くて新しい 材料として，近年見直されてきた．これら無機高分子 は, 地球上に存在する元素の含有量を重量で表わした クラーク数でい总ば， $46.6 \%$ の酸素と $27.7 \%$ のケイ 素を主元素としたものが多く，大きな存在比率を占め ている.

これに対し，有機化合物を構成する元素のクラーク 数は水素が $0.87 \%$, 炭素が $0.08 \%$ であって, 地球に とっては貴重な元素で少る.これらの展望について尾 島, 永井 ${ }^{3)}$ が本誌で述べているが，炭素－炭素結合か らシロキサン結合への高分子材料の転換を提唱してい ることは同感とするものである。

著者は永年シロキサン結合からなるケイ酸カルシウ ム化合物のトバモライトやン゙ノトライトなどの合成と その応用について研究開発に従事してきた。これらが 建築関係汅どのような理由で応用されているかを例を あげて紹介する。

\section{2. ケイ酸カルシウム水和物の合成}

ケイ酸カルシゥム水和物は今までに確諗されたもの のみでも 26 䅜類あり，さら新しく合成されたり， 新鉱物として発見される可能性があり, 無機化学の中 でも開拓の余地の市る分野である。それらのう方，合 成可能な化合物之不可能な化合物があるが，その

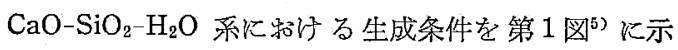
于.

通常, 結晶性のゲイ酸カルシウム水和物を生成する 条件としては, オートクレーブ反応と呼ばれる飽和水 蒸気中での加熱反応が必要であり，その生成する合成 化合物の種類柱として $\mathrm{CaO}$ と $\mathrm{SiO}_{2}$ モル比と, 加 熱温度, 反応時間に左右される。これら合成される 化合物の中で最も工業的に有用な化合物は, シロキサ ン鎖岁るいは層 (layer) からなるワラストナイトグル ープ (wollastonite group) とトバモライトグループ 


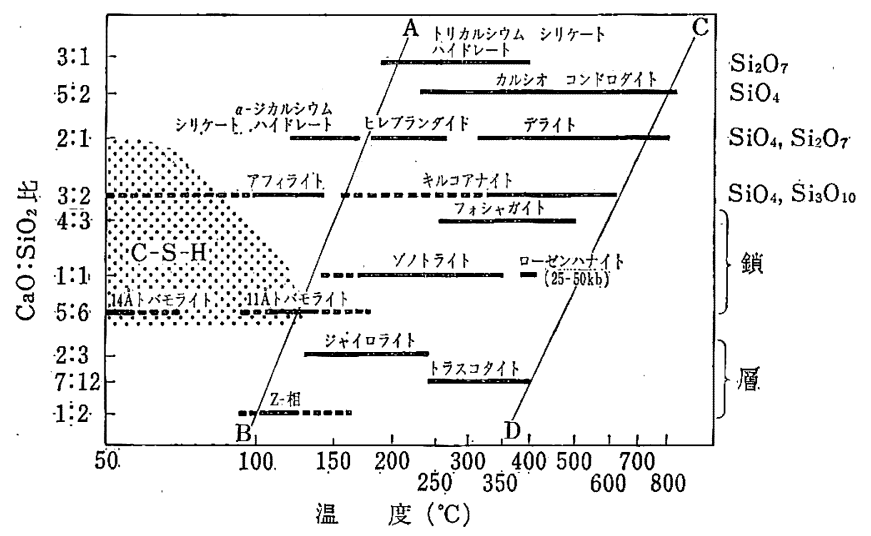

第 1 図ケイ酸カルシウム水和物の生成条件（光田 武5より）
応と結晶化が進行する。

\section{2-1. トバモライトグループ}

トバモライトグループは，特よそ $180^{\circ} \mathrm{C}$ 以下の水熱反応淢いて, $2 \leq \mathrm{CaO} / \mathrm{SiO}_{2} \leq 0.83$ のモル比で生 成する化合物であり，その構造が $11.3 \AA$ トバモライトの構造と相似 している化合物である点から，とれ らを総称したグループである．出発 原料は $\mathrm{CaO}$ および $\mathrm{SiO}_{2}$ であるが， ポルトランドセメントの $3 \mathrm{CaO}$. $\mathrm{SiO}_{2}, 2 \mathrm{CaO} \cdot \mathrm{SiO}_{2}$ などでもさしっ かえない，一般的に常压下で $\mathrm{CaO}$ と $\mathrm{SiO}_{2}$ を水中で反応せしめたとき，

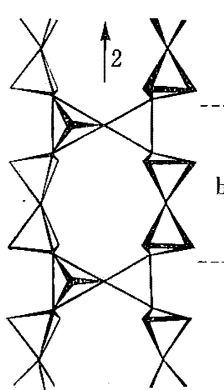

(a)

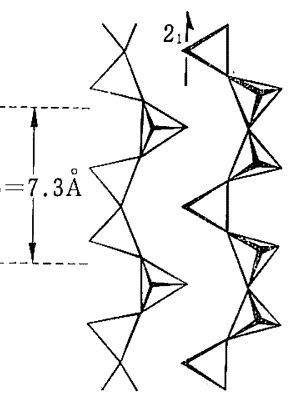

(b)
第 2 図 ゾノトライト(a)と $\beta$-ワラストナイト(b) の $\mathrm{Si}-\mathrm{O}$ 鎖構造 (H.F.W. Taylor ${ }^{6)}$ より)

(tobermorite group) であり，それらに関する研究 報告は数多くある.

ワラストナイト鎖は第 2 図に示すように，シロキサ ン鎖を骨格構造としており，3 個の $\mathrm{SiO}_{4}$ 四面体でも ってその鎖の周期が $7.3 \AA$ となり，その側鎖として $\mathrm{Ca}-\mathrm{O}$ 八面体が位置した鎖をいう．このワラストナイ 卜鎖を基本構造とする化合物のらら，水熱反応で生成 する化合物の主なものはゾノトライト（xonotlite）, フォシャガイト (foshagite), ヒレンブランダイト (hillenbrandite), $14 \AA$ トバモライト, 11.3 モライト, $9.3 \AA$ トバモライト, 準結晶性トバモライ トの C-S-H ( I ) や非晶質に近いトバモライトの C$\mathrm{S}-\mathrm{H}$ (II) などである。通常 $\mathrm{CaO} / \mathrm{SiO}_{2}$ モル比う1 と して水熱反応するとき, およそつぎのような経過で反

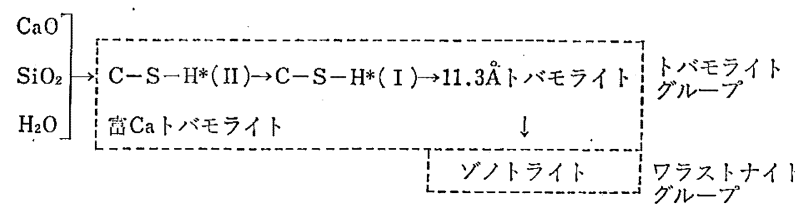

あるいはポルトランドセメントを水和したときは，結 晶化が進んでもはく状または絨維状の準結晶性トバモ ライト C-S-H (I) で止まるが, これを $100^{\circ} \mathrm{C}$ から $180^{\circ} \mathrm{C}$ の間の 飽和水蒸気圷下で反応せしめると, 板 状の結晶性 $11.3 \AA$ トバモライトが生成する。これら の化合物の分類は H.F.W. Taylor ${ }^{6)}$ のX線回折法に よる分類法に従うことが通例となっている.

11.3̊̊ドモライトは三次元的に成長した結晶性化 合物であり，C-S-H (I) は二次元的，すなわら ( hk0) の反射が主であることから $a$ 执よび $b$ 軸方向の層平 面の成長のみで, $c$ 軸方向の積層が十分でない準結晶 性化合物でめり, C-S-H（II）は 1〜3 本の ( $h k)$ の 回折線からみて $a$ 执よび $b$ 軸方向の層平面からなる

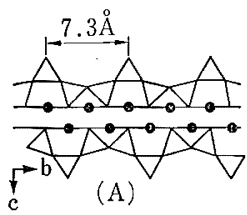

第 3 図トバモライトの

結晶構造之加蓺変化

(光田武ら)より)

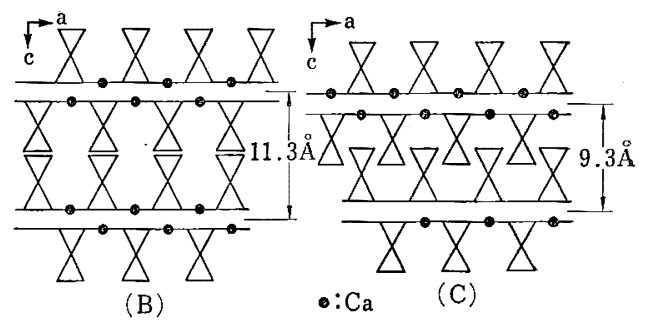

非晶質に近い化合物であることがわかる。

トバモライトの結晶構造は H.D. Megaw ${ }^{7}$ によって決定され，その構造の理想的構造を 第 3 図 $A, B$ に示す. トバモライトは一般には $5 \mathrm{CaO} \cdot 6 \mathrm{SiO}_{2} \cdot 5 \mathrm{H}_{2} \mathrm{O}$ あるいは $\mathrm{Ca}_{4}\left(\mathrm{Si}_{3} \mathrm{O}_{9} \mathrm{H}\right)_{2}$ ・
* セメント化学で法次の略号を使用する. $\mathrm{C}: \mathrm{CaO}, \mathrm{S}: \mathrm{SiO}_{2}$ $\mathrm{H}: \mathrm{H}_{2} \mathrm{O}$
$\mathrm{Ca} \cdot 4 \mathrm{H}_{2} \mathrm{O}$ で表わされている. その構造は $\mathrm{Ca}-\mathrm{O}$ と $\mathrm{Si}-\mathrm{O}$ の連結した層からなり,その層は前述の三個の 
$\mathrm{SiO}_{4}$ 四面体とその側鎖 $\mathrm{Ca}-\mathrm{O}$ からなるワラストナイ ト鎖を基本構造とし, $7.3 \AA$ の周期がある. そして, これらの層が $c$ 軸方向に周期 $11.3 \AA$ で積層して結晶 性トバモライトとなるが， C-S-H (II) や C-S-H (I) はこの層の積層に不整があるるのと解釉される。すな わち, 積層不整は結晶化に従って消隇してゆくすので ある、また， C-S-H (I) や C-S-H（II）の構造はこ れらの層の相互間の角度が約 $60^{\circ}$ で交差するもので あるといわれている、いずれにしてる，これらトバモ ライトグループは $\mathrm{SiO}_{4}$ 四面体の連鎖であるシロキサ ン鎖構造を骨格としていることが特徴である。

C. W. Lentz ${ }^{11}$ はトバモライトやポルトランドセメ ントの水和物をトリメチルシリル化し, 得られたトリ メチルシリルポリシリタート誘導体から逆にこれらの シロキサン鎖の構造について検討した．この方法を利 用し，小松ら ${ }^{8,99}$ は合成ヶイ酸カルシウムのトバモラ イトゲル,トバモライト,ゾノトライトについて調 ベ, ケイ酸カルシウムの生成時の水熱反応の段階で, シロキサン鎖の縮合成長反応が順次進行してゆくもの と解釈した。 また Al を含むトバモライトの場合，そ の誘導体はシロキサン結合 (-Si-O-Si-) はアルミノキ サン結合 (-A1-O-) でブロックされ，

$$
-(\mathrm{Si}-\mathrm{O})_{5}-\mathrm{Al}-\mathrm{O}-(\mathrm{Si}-\mathrm{O})_{5}-
$$

となることが分子量からわかり, $\mathrm{Si}: \mathrm{Al}$ の原子比が 5〜6:1 であることを示し, S. Diamond ${ }^{10)}$ らの Alトバモライト合成汇括ける $\mathrm{Al} \rightleftarrows \mathrm{Si}$ 置換の最大比率と よい一致を示した。をた，これらのトリメチルシリル 化による有機溶媒可溶揮発成分は一重鎖状構造のポり シリケート (I）式, 不揮発成分は二重鎖状構造のポ リシリケート（II）式で表わされることを示した.

$\left(\mathrm{CH}_{3}\right)_{3}-\mathrm{Si}-\mathrm{O}\left(\begin{array}{l}\mathrm{OSi}\left(\mathrm{CH}_{3}\right)_{3} \\ 1 \\ -\mathrm{Si}--\mathrm{O}-\mathrm{O} \\ 1 \\ \mathrm{OSi}\left(\mathrm{CH}_{3}\right)_{3}\end{array}\right)_{n} \mathrm{Si}\left(\mathrm{CH}_{3}\right)_{3}$

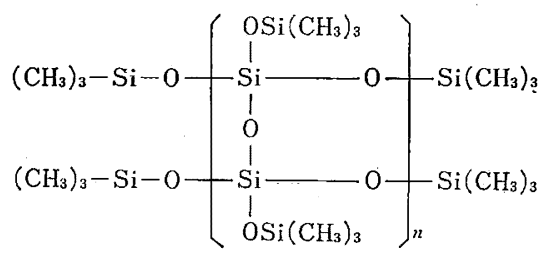

トバモライトゲルは（I）式と（II）式のポリマーか らなり，結晶性トバモライトは（II）式の二重鎖状構 造のポリシリタート $(n=18)$ に近く, Al-トバモライ トは (I) 式の $(n=2)$ と（II) 式の $(n=5 \sim 6)$ のポ リシリケートからなることを示した。これらのことか ら結晶性トバモライトのシロキサン構造は二重鎖状構 造であり, 初期反応生成物のゲルは一重鎖状の短い構
造であることを示唆している.

\section{2-2. ワラストナイトグループ}

ワラストナイトグループの中で最も合成しやすく， からまた最も有用な化合物はゾノトライトで㐫る・ゾ ノトライトは $\mathrm{CaO} / \mathrm{SiO}_{2}$ モル比=1 で $150 \sim 400^{\circ} \mathrm{C}$ の飽和水蒸気圧下で水䓡反応するとさ生成する針状采 たはラス状の結晶である. 分子式は $\mathrm{Ca}_{6} \mathrm{Si}_{6} \mathrm{O}_{17}(\mathrm{OH})_{2}$

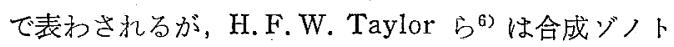
ライトについて実駼值から $5 \mathrm{CaO} \cdot 5 \mathrm{SiO}_{2} \cdot \mathrm{H}_{2} \mathrm{O}$ を提案 している. K.S. Mamedov'11) らの天然ゾノトライト の結晶構造解析に上れば， $\left(\mathrm{SiO}_{4}\right)$ 四面体で 8 員環を つくりこれが連続して連結したいわゆるゾノトライ トリボンの骨格構造を形成し，旮の連鎖の伸長方向が $b$ 軸方向となって，その周期が $7.3 \AA$ となっている. この周期はトバモライトの結晶構造の $b 0$ と同じでめ る(第 2 図).

このゾノトライトの結晶化の過程に朔いて, トバモ ライトを経過するか, または, 反応条件や出発原料火 よってはトバモライトを経過せずに C-S-H（I）から 直接ゾノトライトへ移行する。この反応過程の美は特 に原料シリカの反応性に基因するところが大である。 この合成ゾノトライトのトリメチルシリル化の研究で 小松 $\left.{ }^{(8)}, 9\right)$, 椎原 $\left.{ }^{2}, 11\right)$ は，(I) 式の一重鎖状構造のポ リシリケートでなく（II）式の二重鎖状構造のポリシ リケートであり，反応によってシロキサン鎖状構造の 縮合が進行して行くことを明らかにした。

\section{3. ケイ酸カルシウム水和物の一般的特性}

ケイ酸カルシウム水和物の加熱変化の主なものは, $\mathrm{H}_{2} \mathrm{O}$ 分子と $\mathrm{SiOH}$ の分解による変化である. $11.3 \AA$ トバモライトは示差熱分析㮩いて $100 \sim 300^{\circ} \mathrm{C}$ の 間で脱水があり， $9 \AA ̊$ トバモライトに転化し，さらに $800^{\circ} \mathrm{C}$ 付近の脱水と $830^{\circ} \mathrm{C}$ 付近での発熱により, $\beta$ ーワラストナイト $\left(\mathrm{CaSiO}_{3}\right)$ の結晶が生成する，この 熱変化は第 3 図 B, C のトバモライトの構造変化で明 らかなように, $11.3 \AA ̊$ トバモライトのトバモライト 層間の脱水により鎖の充てんが稠密化し， $c$ 軸方向の 面間隔 $d_{002}$ が $11.3 \AA$ から $9.3 \AA$ 亿移行することが わかったささらに高温加熱していくと $\mathrm{OH}$ イオンの 脱水とワラストナイト鎖の再配列により， $\beta$ ーワラス トナイトになる。

一方, ゾノトライトの加熱変化は非常に単純であ. り、ゾノトライトリボンの二重鎖状構造が切断して, 一重鎖状構造のワラストナイト鎖へ移行する変化であ. りこれは $750 \sim 800^{\circ} \mathrm{C}$ の付近の $\mathrm{OH}$ イオン脱水と 同時に起こるものである (第 2 図).しかし、ゾノト ライトの加熱に敊ける特徽は，加熱によってワラスト 
第 1 表 各種ケイ酸カルシウム水和物の物性

\begin{tabular}{|c|c|c|c|c|c|c|c|c|c|c|c|}
\hline \multirow{2}{*}{ 化 合 物 } & \multirow{2}{*}{ 組成式 } & \multirow{2}{*}{$\begin{array}{l}\text { 主要な加熱 } \\
\text { 減量温度 } \\
\left({ }^{\circ} \mathrm{C}\right)\end{array}$} & \multicolumn{3}{|c|}{ 比強度 $=\frac{\text { 強 度 }}{(\text { カサ比重 })^{2}}$} & \multirow{2}{*}{$\begin{array}{l}\text { 安全最 } \\
\text { 高温度 } \\
\left({ }^{\circ} \mathrm{C}\right)\end{array}$} & \multirow{2}{*}{$\begin{array}{c}1,000^{\circ} \mathrm{C} \\
\text { の灼熱娍 } \\
\text { 量率 } \\
(\%)\end{array}$} & \multicolumn{3}{|c|}{$\begin{array}{c}\text { 加熱収縮率 } \\
3 \mathrm{hr} \text { 加熱 }(\%)\end{array}$} & \multirow{2}{*}{$\begin{array}{l}\text { 比表面積 } \\
\left(\mathrm{m}^{2} / \mathrm{g}\right)\end{array}$} \\
\hline & & & 圧 縮 & 曲 & $ケ^{\circledR}$ & & & $650^{\circ} \mathrm{C}$ & $850^{\circ} \mathrm{C}$ & $1,000^{\circ} \mathrm{C}$ & \\
\hline C-S-H (I) & $\mathrm{C}_{1 \sim 1.5} \mathrm{SH}_{x}$ & $20 \sim 500$ & 203 & & 28 & 400 & $12 \sim 16$ & 4.2 & 崩壊 & - & 135 \\
\hline $\begin{array}{l}11.3 \AA \\
\text { トバモライト }\end{array}$ & $\mathrm{C}_{5} \mathrm{~S}_{6} \mathrm{H}_{5}$ & $100 \sim 300$ & 67 & & 27 & 650 & 12.33 & 2.2 & 2.9 & 3.4 & 39 \\
\hline ゾノトライト & $\mathrm{C}_{6} \mathrm{~S}_{6} \mathrm{H}$ & $680 \sim 700$ & 113 & & 71 & 1,050 & 3.01 & 0 & 0.6 & 0.6 & 68 \\
\hline フォシャガイト & $\mathrm{C}_{4} \mathrm{~S}_{3} \mathrm{H}$ & $650 \sim 750$ & 一 & & - & 1,000 & 4.27 & - & 一 & 一 & 115 \\
\hline $\begin{array}{l}\text { トリカルシウム } \\
\text { シリケート水和物 }\end{array}$ & $\mathrm{C}_{3} \mathrm{SH}_{1.5}$ & $420 \sim 550$ & 68 & & 50 & 550 & 10.59 & & & & \\
\hline
\end{tabular}

Butt, et al. 14) より引用

ナイトへ転化しても，結晶の外観に拈いて電子顕微鏡 下でまったく変化がみられないといらことである。こ の反応を H.F.W. Taylor ${ }^{6}$ 性研究し，トポタクチッ ク (topotactic) 反応であると述べている.

ケイ酸カルシウム水和物の結晶のみの機械的特性の データはないが，見掛け比重が1亿近い成形体の強 度 ${ }^{14)}$ 中，熱特性，比表面積18) Kついて第 1 表に示す。 この第 1 表でかかるように, ゾノトライトは耐熱度が 高く，曲げ強度が大であることが特徵であり，また，
C-S-H (I) は圧縮強度が大であるが，耐熱度が低いと いう欠点が离る。

\section{4. ケイ酸カルシウム系建材}

完全不燃の建材としてのケイ酸カルシウム系建材 （オートクレーブ製品）の製造法は大別すると四つに 分類される。それらの製造法と製品の特性特よび利用 の概要を第 2 表に示す。

これらの各種ケイ酸カルシウム系建材の材料成分の

第 2 表 ケイ酸カルシウム製品の工程と物性

\begin{tabular}{|c|c|c|c|c|c|c|}
\hline \multirow[b]{2}{*}{ 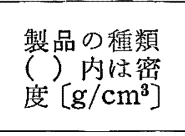 } & \multirow[b]{2}{*}{ 原 料 } & \multirow{2}{*}{ 成 形 } & \multicolumn{3}{|c|}{ 物 性 例 } & \multirow[b]{2}{*}{ 主な用途 } \\
\hline & & & $\begin{array}{c}\text { 密 度 } \\
\left(\mathrm{g} / \mathrm{cm}^{3}\right)\end{array}$ & $\begin{array}{c}\text { 曲げ強度 } \\
(\mathrm{kg} / \\
\left.\mathrm{cm}^{2}\right)\end{array}$ & $\begin{array}{l}\text { 安全最 } \\
\text { 高温度 } \\
\left({ }^{\circ} \mathrm{C}\right)\end{array}$ & \\
\hline $\begin{array}{l}\text { (1) ヶイ酸カ } \\
\text { ルシウム成 } \\
\text { 形板 } 25 \mathrm{~mm} \\
\text { 厚以上 } \\
(0.2 \sim 0.5)\end{array}$ & 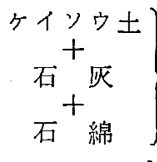 & $\left\{\begin{array}{l}\rightarrow \text { 膨潤ゲル化 } \rightarrow \text { ィルタープレス } \\
\quad \rightarrow \text { } \\
\quad\left(>170^{\circ} \mathrm{C}\right)\end{array}\right.$ & 0.48 & 37 & 650 & $\begin{array}{l}\text { 保温材・耐火被覆 } \\
\text { 材 } \\
\text { 内装壁・パネル芯 } \\
\text { 材 }\end{array}$ \\
\hline & $\left.\begin{array}{c}\text { ケイ砂 } \\
+ \\
\text { 石 }^{+} \\
\text {石 }^{+} \text {綿 }\end{array}\right\}$ & 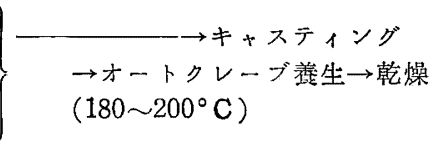 & & & & \\
\hline $\begin{array}{l}\text { ケイ酸カル } \\
\text { シウムボー } \\
\text { ド } 12 \mathrm{~mm} \text { 厚 } \\
\text { 以下 } \\
(0.8 \sim 1.0)\end{array}$ & $\begin{array}{c}\text { ケイウ土 } \\
+ \\
\text { 石灰 }^{+} \\
\text {石 }\end{array}$ & $\begin{array}{l}\longrightarrow \text { 抄造機 } \\
\longrightarrow \text { オートクレーブ養生 } \rightarrow \text { 乾燥 }\end{array}$ & 0.7 & 180 & 850 & 天井材・壁 \\
\hline \multirow{3}{*}{$\begin{array}{l}\text { (2) ケイ酸カ } \\
\text { ルシウム成 } \\
\text { 形板 } \\
(0.1 \sim 0.5)\end{array}$} & \multicolumn{2}{|c|}{ （結晶スラリー成形法） } & 0.10 & 4 & 850 & 偨温材 \\
\hline & ケイ酸 & \multirow{2}{*}{$\begin{array}{c}\rightarrow \text { ー トクレーブ反応 } \rightarrow \text { フィルタ } \\
\left(>190^{\circ} \mathrm{C}\right) \\
- \text { プレス } \rightarrow \text { 乾燥 }\end{array}$} & 0.20 & 4 & 1,050 & 壁 - 保温断熱材 \\
\hline & 石 灰 & & 0.50 & 45 & 1,050 & 耐火被覆材 \\
\hline \multirow{2}{*}{$\begin{array}{l}\text { (3) ALC (発 } \\
\text { 泡軽量コ的) } \\
\text { クリート) } \\
(0.5 \sim 1.0)\end{array}$} & $\begin{array}{l}\text { ケイ砂 } \\
\stackrel{+}{\text { セメント }}\end{array}$ & \multirow{2}{*}{ 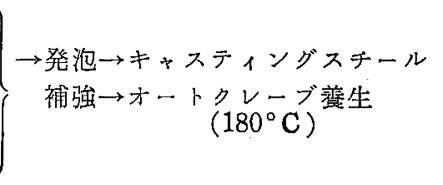 } & 0.5 & 10 & 850 & \multirow[t]{2}{*}{ 壁・断熱材 } \\
\hline & $\begin{array}{c}\text { or 石成 } \\
+ \\
\text { Al }\end{array}$ & & 1.0 & 26 & 850 & \\
\hline \multirow{2}{*}{$\begin{array}{l}\text { (4) サンドラ } \\
\text { イムブリッ } \\
ク(ケ イ \sqrt{ } \\
\text { れんが) } \\
(1.0 \sim 1.6)\end{array}$} & $\begin{array}{c}\text { ケイ砂 } \\
+\end{array}$ & \multirow{2}{*}{$\begin{array}{c}\longrightarrow \text { 強圧プレス } \\
\longrightarrow \rightarrow \text { } \\
\left(200 \sim 220^{\circ} \mathrm{C}\right)\end{array}$} & 1.0 & $\begin{array}{r}\text { 生縮 } \\
75\end{array}$ & 850 & 外装壁材 \\
\hline & 石 ${ }^{\top}$ 灰 & & 1.6 & 250 & 850 & 間仕切り壁 \\
\hline
\end{tabular}


主流はトバモライトグループの C-S-H（I）あるいは 結晶性 $11.3 \AA$ トバモライトである。トバモライトグ ループの加熱線収縮率は $100 \sim 300^{\circ} \mathrm{C}$ の脱水と $850^{\circ} \mathrm{C}$ 付近の $\beta$-ワラストナイトへの移行でもって急激に上 昇し，き裂収縮が著しく，原形を保つことがむずかし い，そ机ゆ兄 $1,000^{\circ} \mathrm{C}$ 以上の耐火性能を必要とする 部材としては皦密にい党ば不適当であるが，その断熱 性のために表面部のみがき裂崩壊するが内部をでは影 響しない場合も西る. しかし, 長時間 $1,000^{\circ} \mathrm{C}$ 以上 の加熱に対して耐觉られない，一方、ゾノトライトの 加熱収縮率は $1,000^{\circ} \mathrm{C}$ でもわずか $0.6 \%$ であり，ゾ ノトライトの結晶の微視的観察に批いても,トポタク チック反応により結晶自体の変形がみられない特徴を 示し， $1,000^{\circ} \mathrm{C}$ に十分に耐克る材料である. その ため, ゾノトライトを主成分とする成形板は JIS-A 1304 の耐火試験に括いて, $1,050^{\circ} \mathrm{C}, 3$ 時間の加熱で もき裂崩壊などはまったく起こらず，強度低下も少な く，耐火材としての耐火性能を十分発揮するるので出 る.な特, ゾノトライトの示差熱分析では $700^{\circ} \mathrm{C}$ 付 近の $\mathrm{OH}$ イオン脱水のみで，特に特徴あるピークは 存在しない熱変化を示す.

以上の性能を総括すると, ゾノトライト系建材は軽 量性, 曲げ強度が大, 耐火度が高いといら特徴を有 乙, トバモライト系建材は柽量性, 王縮強度が大, 耐 火度 $800^{\circ} \mathrm{C}$ 以下といら特致を有する. このように特 徴を生かした新しい分野への進出が今後の開発の課題 として㟧る. そこで，ケイ酸カルシウム系成形体の超 軽量化之高強度化をわれわれ研究陣が挑戦したので, その一端をここに紹介する。

\section{5. 超軽量成形体用ケイ酸カルシウム中空球体}

無機化合物からなる中空微小球体として, ガラス, シラス,カーボン, アルミナなどのバルーンマイクロ カプセルが知られて呿り，複合材料の開発研究が行な われている。

この中空微小球体の利点は, 樹脂や金属との混合性 や成形性がよく，その成形体が軽量で比強度が高い断 熱材料とすることができる点である.われわれは上記 のゾノトライトの特性を生かした中空微小球体を製造 するべく研究した結果, $3 \sim 20 \mu \mathrm{m}$ 程度の長さを有す るゾノトライト結晶を約 $10 \sim 100 \mu \mathrm{m}$ の直径の球状に 凝集させて中空体の球殼の製造に成功した.

久保和彦ら ${ }^{15)}$ のゾノトライト結晶の凝集二次粒子の 生成過程に関する研究によれば, $191^{\circ} \mathrm{C}$ の水熱条件下 で 1 時間にトバモライトの結晶の塊状粒子を形成し， 2 時間後にそそが球状化し，4 時間後にゾノトライト の結晶に転化し, しか子球状の周辺部はイガ栗状とな

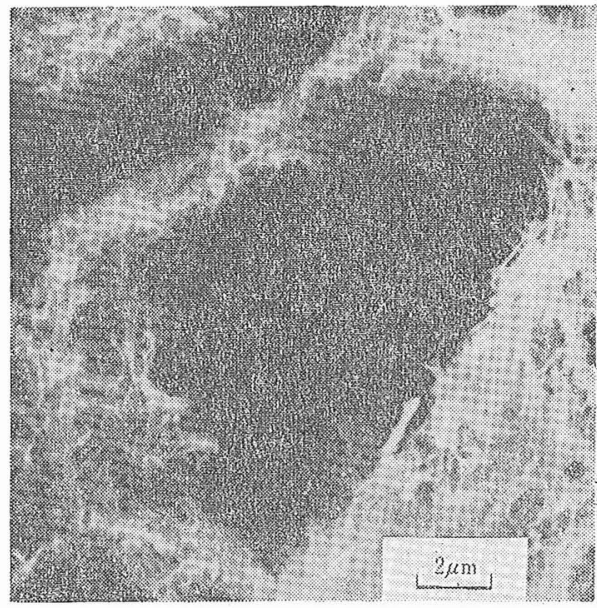

第 4 図 ゾノトライト中空球体の走査型電子 顕微鏡写真

第 3 表 ゾノトライ中空球体の特性例

\begin{tabular}{lll}
\hline \hline 中空球体の外径 $(\mu \mathrm{m})$ & $10 \sim 60$ \\
見掛け密度 & $\left(\mathrm{g} / \mathrm{cm}^{3}\right)$ & $0.07 \sim 0.13$ \\
球殼の平均厚さ $(\mu \mathrm{m})$ & 3 \\
空隙率 (平均) & $(\%)$ & 95.5 \\
DOP 吸油量 & $(\mathrm{m} l / 100 \mathrm{~g})$ & 600 \\
真比重 & $\left(\mathrm{g} / \mathrm{cm}^{3}\right)$ & 2.48 \\
比表面積 & $\left(\mathrm{m}^{2} / \mathrm{g}\right)$ & 52 \\
$\mathrm{pH}$ & & 9.3 \\
\hline
\end{tabular}

ることを示した．その後の研究に㐨いて，1５ $\mu \mathrm{m}$ の 球殼をゾノトライト結晶のからみあいによって形成 し，内部は完全に中空であり，殼は通気性のある中空 球体の製造法を見いだした，その中空球体の直径は約 10 100 $\mu \mathrm{m}$ であり，その外殼部の密度は製造法によ ってコントロールすることが可能である.これら中空 球体の特性例を第 3 表 ${ }^{177}$ 亿示守。

この中空球体を主成分とする複合系として，ガラス

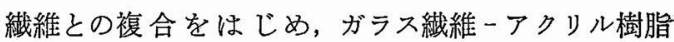
系，石綿一七ッコウ系について検討したが，その中の 一例としてガラス緉維との複合例を示す，ガラス繊維 $10 \%$ ，ゾノトライト中空球体 $90 \%$ の複合成形体では, 見掛け比重が $0.1 \mathrm{~g} / \mathrm{cm}^{3}$ といら超軽量化ができそ の曲げ強度は $4.3 \mathrm{~kg} / \mathrm{cm}^{2}, 70^{\circ} \mathrm{C}$ に打方熱伝導率が $0.039 \mathrm{kcal} / \mathrm{m} \cdot \mathrm{h} \cdot \operatorname{deg}$ といら低い值となり，断熱材料 としては新しい発展を遂げることに成功した。また， 見掛忷比重が $0.48 \mathrm{~g} / \mathrm{cm}^{3}$ の成形体は曲げ強度が 101.7 $\mathrm{kg} / \mathrm{cm}^{2}$, 熱伝導率が $0.060 \mathrm{kcal} / \mathrm{m} \cdot \mathrm{h} \cdot \mathrm{deg}$ であり. 高強度で軽量な断熱壁用として有望であることがわか った．アクリル樹脂との複合では，樹脂 $5 \%$ ，ガラス 繊維 10\%，ゾノトライト中空球体 85\% としたとさ， 見掛け比重が $0.61 \mathrm{~g} / \mathrm{cm}^{3}$, 曲げ強度 $206.3 \mathrm{~kg} / \mathrm{cm}^{2}$ 
という結果を得た。

な㧍，上記の中空球体一ガラス繊維系の複合体は，

『超埾量耐火断熱材に関する研究」で通産省重要技術 開発補助金をらけて開発し，「ダイパライト」といら 商品名で企業化に成功した。

このように，ケイ酸カルシウム結晶の中空球体化と その複合系によって，これまでにないよらな優れた特 性が得られたことから，無機高分子の多機能化とるい える材料として多方面の活用分期待されると考光る. この中空球体の特徵を列記するとつぎのようである.

1) 軽い

2）比強度が大きい

3）耐火性，断熱性などの熱特性が優れている

4) 吸着能が大きい

5) 加工性加よい

6）無公害である

以上の特徵から当面の利用としては，省エネルギー 関係では産業機器やプラントの保温断熱, 建築用とし ては保温斨熱を兼社た壁，天井材や耐火被覆材用であ り, その他, 触媒担体, キャリヤー, 洰過材, 充てん 材などへの利用がある。

\section{6.おわりに}

以上，無機高分子とあいえるケイ酸カルシウム水和 物の代表的なトバモライトとゾノトライトについて簡 単に説明し，さらに多機能化をねらった䇥機中空微小 球体の諸特性および複合による特性の相乗効果の可能 性について例をあげて述べた，今後，このケイ酸カル シウム中空球体との複合によって，今までにない新材 料を生久出すかもしれないといら期待もあるので, 読 者の頭の片隅に入れておいていただければ著者の喜び とするとこるである。

終りにこれらの一連の研究に終始ご指導いただい
た故東京大学教授 山口悟郎先生, 大阪大学教授 田村 英雄先生に，またご援助をいただいた通産省工業技術 院大阪工業技術試験所林 英雄主任研究官に対し, 深 く感謝の意を表します，さらに，本研究の遂行と発表 に際し，指導と許可をいただいた大阪パッキング製造 所社長 柿木克已氏，同工場長 久保和彦氏飞対し深く 感謝の意を表します。

\section{文献}

1) C. W. Lentz: Sposium on Structure of Portland Cement Paste and Concrete, Washington, Highway Research Board, Special Report, No. 90, 269 (1966)

2) 椎原 唐：有合協誌, 30,846 (1972)

3）尾岛 撖, 永井洋一郎：高分子, 23, 19 (1974)

4）高橋 輝, 林 英雄：セメント技術年報, 26, 75 (1972)

5) 光田 武：Chemistry and Industry of Calcium Silicates

6) H.F.W. Taylor: The Chemistry of Cements, Vol. 1, Chap, 5, Academic Press (1964)

7) H. D. Megaw: Acta Cryst., 5, 477 (1952)

8）小松宏二, 遠山一郎, 川原昭宣, 中村富三: 工化 誌，74，160 (1971)

9）小松宏二，遠山一郎，川原昭宣，中村富三，高橋 輝：大工試季報，22，288(1971)

10) S. Diamond, et al. : Amer. Mineral., 51, 388 (1966)

11) K. S. Mamedov, N. V. Belov: Dokl. Akad. Nauk SSSR., 123, 163 (1958)

12) 椎原 庸：高分子, 24, 517 (1975)

13）高橋 辉：工業技術，14，No. 3，39 (1973)

14) Y.M. Butt, et al.: Sborn. Trud. Resp. Nauchnoiss led. Inst. Stroitel. Materialov., No. 17, 66 (1960)

15）久保和彦ら：墨協誌，82［8] 414 (1974)

16）久保和彦，高木茂栄：䇺協誌，86 [2] 15 (1978)

17) 高橋 輝：化学工業, 74, 858 (1977) 